\title{
Addressing social and gender inequalities in health among seniors in Canada
}

\author{
O enfrentamento das desigualdades sociais \\ e de gênero entre idosos no Canadá
}

Louise A. Plouffe 1

\footnotetext{
1 Division of Aging and Seniors Health Canada. Tunney's Pasture 1908A1, Ottawa, Ontario, Canada K1A $1 B 4$
}

\begin{abstract}
Although canadian seniors enjoy economic security and good health and have made substantial gains in recent decades, this well-being is not equally shared among socioeconomic groups and between men and women. As for younger age groups, income predicts health status in later life, but less powerfully. Potential alternative explanations include an overriding influence of the aging process, the subjective effects of income loss at retirement and the attenuation of the poverty gap owing to public retirement income. Older women are more likely to age in poverty than men, to live alone and to depend on inadequately resourced chronic health care and social services. These differences will hold as well for the next cohort of seniors in Canada. Addressing these disparities in health requires a comprehensive, multisectoral approach to health that is embodied in Canada's population health model. Application of this model to reduce these disparities is described, drawing upon the key strategies of the population health approach, recent federal government initiatives and actions recommended to the government by federal commissions.
\end{abstract}

Key words Equity; Gender; Aging; Social Conditions

Resumo No Canadá, os idosos gozam de segurança econômica e de boa saúde e têm experimentado ganhos substanciais nas últimas décadas; no entanto, esse bem-estar não é compartilhado de maneira eqüitativa entre grupos sócio-econômicos de idosos, nem entre homens e mulheres. Nas faixas etárias mais jovens, o nível de renda prediz o estado de saúde nas fases de vida subseqüentes, mas essa correlação é menos forte do que na própria terceira idade. As diversas explicações incluem a preponderância do próprio envelhecimento biológico e os efeitos subjetivos da perda de renda associada à aposentadoria, além da atenuação das diferenças sócio-econômicas em função da aposentadoria mínima garantida pelo estado. Comparadas aos homens, as mulheres idosas têm maior probabilidade de envelhecer em situação de pobreza, de viver sozinhas $e$ de depender de assistência médica crônica e de serviços sociais sem recursos adequados. Pode-se esperar que essas diferenças persistam na próxima coorte de idosos canadenses. O enfrentamento das disparidades em saúde requer uma abordagem abrangente e multi-setorial que esteja incorporada ao modelo populacional de saúde do Canadá. A aplicação desse modelo é analisada no sentido de reduzir as disparidades, citando as principais estratégias da abordagem populacional à saúde, além de iniciativas recentes do governo federal canadense e medidas recomendadas ao governo por comissões federais.

Palavras-chave Eqüidade; Gênero; Envelhecimento; Condições Sociais 
In many ways, Canada is a good place for men and women to live and grow old. The 1998 United Nations Development Report ranked Canada the best in the world in terms of overall human development as measured by life expectancy, educational attainment and income (UNDP, 1998). Canadians are living longer and with fewer disabilities in old age. However, this rosy picture has a darker underside: there are distinct inequalities in health among Canadians: the same UN Report dropped Canada's ranking to the $10^{\text {th }}$ place among industrialized countries on its Human Poverty Index, observing that the country has significant problems of poverty and that progress in human development has been poorly distributed (UNDP, 1998). The federal and provincial governments are aware of the disparities in health among Canadians and have approved a policy approach aimed at identifying and addressing the economic, social, environmental and behavioral determinants of health (Health Canada, 1998). This paper will review the trends in health among seniors (i.e., age 65+), looking specifically at socioeconomic status and gender as important determinants of health, and will describe current policy approaches and initiatives designed to reduce these disparities.

\section{Canada's seniors}

First, a quick overview of aging and seniors in Canada (Statistics Canada, 1999b). The total Canadian population is around 35 million, and seniors (people aged 65+) constitute $13 \%$ of the population, or some 3.9 million. $76 \%$ of seniors live in urban areas, compared to $79 \%$ of Canadians in general. $56 \%$ of the seniors population are women, and their proportion is higher among older seniors. Most seniors either live with a spouse or they live alone: it is not common for seniors to live in the same home as their adult children. Living alone is more common among senior women: $38 \%$ live alone, compared to $16 \%$ of men. Although Canada is aging now, starting in 2011, the country will age even more rapidly, as baby boomers begin to reach the age of 65 . By 2036, it is expected that seniors will constitute $23 \%$ of the Canadian population, or about 1 in 4 Canadians. The fastest growing age group in Canada are people aged 85+: as a group, these seniors are mainly women living alone, usually with some level of disability that requires care and support.

Thanks to the introduction of a strong old age income system comprising revenue sources from general taxation, social security contribu- tions and private pension plans and savings, poverty rates among Canadian seniors have decreased substantially during the past two decades, from $21 \%$ to $9 \%$ (Statistics Canada, 1997). At present, poverty rates among seniors are lower than those among younger Canadians, whose average poverty rate is $12 \%$ (the poorest Canadians are single women with dependent children). Among seniors, poverty is concentrated among seniors living alone, older seniors and immigrants (mostly people who immigrated to Canada as older adults). In all these groups, women constitute the majority (Larmer, 2001).

\section{The health status of older and aging Canadians}

Canadian seniors are living longer lives in better health than in the past. In 1996, life expectancy at age 65 was 18.4 years, five years longer than in 1941 (Statistics Canada, 1999a). Nine of these 18 years are free of disability, and the remaining years include 3 years each of slight, moderate and severe disability; gains in life expectancy at age 65 have been accompanied by an almost equal increase in health expectancy, meaning that seniors can expect greater vitality for some of the added years of life (Martel \& Bélanger, 1999). The prevalence of some important chronic conditions among seniors, notably heart disease, high blood pressure, arthritis and long-term activity limitations has declined slightly since the 1970s. Seniors increasingly view their health in positive terms, despite the health problems they have. In 1995, $73 \%$ of seniors considered their health to be excellent, very good or good; in 19981999 , this figure improved to $77 \%$ of seniors (National Advisory Council on Aging, 2001). A positive perception of one's health is an indication of a sense of overall well-being that takes into account not only one's problems, but more important, one's capacity to cope with problems: indeed, $85 \%$ of seniors with a long-term limitation in activity report that they are coping well (National Advisory Council on Aging, 2001).

\section{Socioeconomic disparities in health}

These improvements in health have not been evenly shared by all socioeconomic groups. Seniors with less education and from lower socioeconomic levels experience more disease, a shorter life expectancy and poorer emotional 
wellbeing. In 1998-1999, 30\% of seniors with household incomes of less than $\$ 20,000$ saw themselves as being in fair to poor health and $69 \%$ of these people were physically inactive ; in comparison, $20 \%$ of seniors with incomes over $\$ 20,000$ rated themselves in fair to poor health and $58 \%$ were physically inactive (National Advisory Council on Aging, 1999). Seniors with low incomes have increased odds of institutionalization in long-term health care facilities (Trottier et al., 2000). Among seniors with disabilities, those with low incomes are more functionally incapacitated than are those with higher incomes (Raina \& Wong, 2002).

A review by Raina et al. (2000) indicated that the association between income and health is less pronounced among seniors than among younger adults. Indeed, in later life, advancing age is a stronger predictor of health status than income. Three explanations for the phenomenon are possible. The first is that the biological aging process overtakes the effects of economic deprivation on health. The second explanation builds upon evidence that a reduction in income is associated with worsening health: because most Canadians experience some loss of income upon retirement, this decrease in income could have negative effects on their health status, although they may not be classified as poor based on their actual income. Finally, Canada's public retirement income system effectively reduces the poverty gap experienced by low-income seniors, such that seniors are the least disadvantaged of Canada's poor: indeed, improvements in seniors' health have coincided with improvements in their economic situation in recent decades. Thus, it is possible that the reduction of the depth of seniors' poverty also could account for the diminished effect of low income on their health.

\section{Gender disparities in health}

Gender has a significant influence on health and well-being throughout life because gender affects most of the known factors that determine health, including education, occupation, income, social networks, physical and social environments and health services. A recent study (Prus \& Gee, 2002) also showed that the health of senior men and women is differentially vulnerable to various health determinants; whereas older men's health is more strongly affected by education, older women's health is affected more by income, psycho-social factors and stress-related factors. In a word: older women are more vulnerable to poverty than men, and older women's health appears to be more vulnerable to the effects of poverty than is men's health. Gender also affects the health services received by seniors. Cardiovascular disease is the leading cause of death for both sexes with advancing age, but it is more likely to go undiagnosed and untreated in women (Maxwell \& Oakley, 1998). As they become increasingly frail, older women living alone depend on family members for care, and on health and social home care services provided by governments. When they are too frail to have their needs met in the community, and there is often no-one available to provide care at home, they are placed in long-term care institutions. Because home care and institutional long-term care are not part of the publicly-insured universal health system, they are underfunded and the quality and consistency of care is uncertain. As the major users of these services, older women are thus systematically disadvantaged.

How will tomorrow's seniors fare? Overall, the proportion of Canadians with low income increased during the 1990s, although the progressive tax system and income transfer programs have kept income distribution inequalities fairly constant. Analyses of the economic situation of middle-aged Canadians indicate the same degree of income disparity as experienced by current seniors when they were the same age (Gee, 1999; McDonald, 1999), which suggests that tomorrow's seniors will not be better-off economically than are current cohorts and will depend as much on government retirement income programs. While contrary to the past, the majority of women are now in the workforce and are making gains in average earnings, they continue to face a significantly higher risk for low income than do men. They continue to interrupt their paid work more often due to family responsibilities (child care and elder care) and tend to occupy lower-paying jobs in sectors where employment-related pension plans are meager or non-existent. To sum up: the social and gender disparities in health observed among today's seniors will likely continue when today's working-age adults become seniors, and more senior women than men will continue to experience poverty.

\section{A population health approach to address health inequalities}

Understanding the factors underlying inequalities in health is a major feature of Canadian health policy. The federal and provincial gov- 
ernments have adopted a "population health" approach to health which focuses on the interrelated conditions and factors that influence the health of populations over the life course, identifies systematic variations in their patterns of occurrence, and applies the resulting knowledge to develop and implement policies to improve health in general and to reduce health inequalities (Health Canada, 1998). The key determinants of health which are taken into account in planning action to improve health are: biology and genetic endowment, childhood development, education, social environments, social support networks, income and social status, occupation and working conditions, physical environment, personal health practices, health services, culture and gender.

Population health strategies to improve health and reduce inequalities include a number of key elements. They examine the full spectrum of health determinants and their interactions known to affect the health issue in question, and decisions are based on the best objective evidence available. To maximize the health benefits, preferential investments are made in the root causes of illness, that is, "upstream investments". A wide variety of health interventions are applied as dictated by evidence, including health protection, disease prevention, health promotion, as well as action on social, environmental or economic determinants. Implementation of these multiple strategies requires the involvement of all levels of government involved (federal, provincial, regional), as well as the voluntary and private sector. The participation of citizens is promoted to identify problems and implement solutions at the individual and community level. Finally, the population health approach favors public accountability for health outcomes, involving regular surveillance and evaluation.

Concretely, the application of a population health approach to address socioeconomic and gender inequalities in the health of Canadian seniors means taking action on several fronts.

\section{Healthy aging}

Within a population health approach, the Government of Canada seeks to promote healthy aging, which is defined as: " a lifelong process of optimizing opportunities to improve and preserve physical and mental health, social wellbeing, independence and quality of life, and of enhancing successful life-course transitions". With respect to addressing existing, systematic health inequalities among seniors, our approach with- in a population health framework is two-fold: change risk factors before they seriously affect health and minimize the impact of poor health on functional capacity and quality of life. The initiatives and recommendations I will describe next are in the areas of income, housing and health care.

\section{Current policy initiatives and recommended actions}

\section{Income}

The first step in reducing health inequalities in older adult life is reducing socioeconomic disparities, with a particular, although not exclusive, focus on gender. The current public retirement income system is working quite well in minimizing economic differences among seniors; fewer seniors experience low income than other age groups, as well as lower depth of poverty. To reduce low income among tomorrow's seniors, the Government of Canada is funding pilot projects to test innovative approaches that help older workers to remain employed or be re-integrated into the work force. As well, the federal government has developed a skills and learning agenda that will allow older workers to update skills and learn new skills to find and retain employment.

Because working women often sacrifice their own financial wellbeing by leaving the labor force to provide care for disabled family members, the tax system currently allows caregivers to claim a small tax credit to compensate for the cost of providing care. This fall, the government also announced its intention to provide financial support to persons who withdraw temporarily from the workforce to provide care to a family member who is terminally ill. Two weeks ago, a commission mandated by the government to review the Canadian health care system recommended that the government provide funded leave through the Employment Insurance Program to caregivers of persons with chronic illness or long-term disability (Romanow, 2002).

\section{Physical environments}

A second area of intervention addresses the physical environments associated with socioeconomic deprivation and health inequalities. Urban seniors with low incomes (and again, especially women) are more likely to have inadequate rental housing which, moreover, often costs more than they can afford. Both the fed- 
eral and provincial governments had significantly reduced their subsidies for social housing programs during the 1980s and 1990s, although there remained some small federal programs that provided some assistance to low-income homeowners to renovate or repair their homes. Last year, in response to growing public demand for affordable housing especially in large urban areas, the federal government has injected some new funds to subsidize the construction of affordable housing for low-income Canadians, including seniors. More is needed, but this is a good start.

A major cause of hospitalization, disability and mortality among seniors is unintentional injuries, usually resulting from falls. Hazards in and around one's home are an important contributing factor. The substandard living environments of many low-income seniors are more likely conducive to unintentional injuries. In partnership with the Veterans Affairs Canada, Health Canada provides funding to community groups to implement local strategies to prevent falls.

\section{Health services}

Another strategy involves minimizing the impact of health problems on functional independence and quality of life for seniors who are experiencing the consequences of long-standing social inequalities. The Canadian universal health care system is of crucial importance in this regard because all Canadians have access to publicly-funded doctors and hospital services. And, not surprisingly, socioeconomically disadvantaged Canadians use doctors and hospital services more often than wealthier Canadians.

For health services that are not covered by our public health insurance plan, subsidies are provided to seniors and persons with low incomes for prescription drugs, home care and institutional long-term care. However, faced with rising costs for health care, provincial governments have limited funding for non-insured health programs, such that co-payments for drugs have increased, and the adequacy of services provided to home care clients and to residents of long-term care facilities has been questioned. There are many anecdotal reports of insufficient care or care of poor quality and many complaints of under-funding. There is evidence too that the withdrawal of some home care supports for chronically ill or disabled seniors results in a decline in health, as seen in an increase in hospitalization, transfer to institutional care and mortality. Seniors who have higher incomes can supplement the public care with additional services which they pay through private insurance or individual payment, but seniors with low incomes have to make do with the public services provided. Senior women are the principal clients of home care and residents of nursing homes. Reform of the health care system to respond to the changing health needs of Canadians is a major policy issue right now. Two important and high-profile federal commissions have recommended increasing federal funding for health care in general, and both reports recommend significant new investments to improve home care (Romanow, 2002; Standing Senate Committee on Social Affairs, Science and Technology, 2002). In the coming months, the federal government will respond to the recommendations of these commissions, and we will know then whether there will be major improvements in the health care that disproportionately benefits socially disadvantaged seniors.

\section{Gender}

The last area of intervention I will mention addresses gender. The federal government has introduced a Federal Plan for Gender Equity, which makes commitments involving 24 government departments under the leadership of one department (Status of Women Canada). Status of Women works to ensure that federal legislation, policies and programs advance the equality of Canadian women.

Within my Department, Health Canada, there is a Women's Health Bureau, which is responsible for ensuring that women's health concerns get appropriate attention within the Department. The Department has adopted a Women's Health Strategy to increase knowledge about women's health, promote the health of women, support the provision of effective health services to women and make sure that Health Canada's policies and programs are responsive to the differential needs of women. Two pillars of the Strategy are the five Centers of Excellence for Women's Health and the Women's Health Network. Together, the Centers and the Network identify priorities, conduct research and disseminate research findings on women's health.

In conclusion, social and gender inequalities are interdependent in Canada and the effects on health are present at all ages. Reducing these inequalities requires multisectoral approaches to address the various determinants of health. Although much more can and should be done to reduce health inequalities, Canada 
has had some successful policies, especially in providing a stable and adequate income for most of its seniors and in providing a good public health care system.

\section{References}

GEE, E., 1999. Pensions and Population Aging: Reframing the Challenges of the Baby Boom. Ottawa: Canadian Association on Gerontology. (mimeo.)

HEALTH CANADA, 1998. Taking Action on Population Health. Ottawa: Health Promotion and Programs Branch.

LARMER, C., 2001. Low Income Among Canada's Seniors. Ottawa: Human Resources Development Canada. (mimeo.)

MARTEL, L. \& BÉLANGER, A., 1999. An analysis of the change in dependency-free life-expectancy in Canada between 1986 and 1996. In: Report on the Demographic Situation in Canada, 1998-99 (A. Bélanger, ed.), pp. 166-177, Ottawa: Statistics Canada.

MAXWELL, C. \& OAKLEY, K., 1998. Older women's health issues. Canadian Journal on Aging, 17:1-9.

McDONALD, L., 1999. The Dawn of a New Era in Aging: Challenges for Boomers. Ottawa: Canadian Association on Gerontology. (mimeo.)

NATIONAL ADVISORY COUNCIL ON AGING, 2001. Custom Analyses of the 1998-99 National Population Health Survey. Report Card on Seniors in Canada. Ottawa: Supply and Services Canada.

NATIONAL ADVISORY COUNCIL ON AGING, 1999. 1999 and Beyond: Challenges of an Aging Canadian Society. Ottawa: Supply and Services Canada.

PRUS, S. G. \& GEE, E., 2002. Gender Differences in the Influence of Economic, Lifestyle and Psychosocial Factors on Later-life Health. Hamilton: Program for Research on Social and Economic Dimensions of an Aging Population, McMaster University.

RAINA, P. \& WONG, M., 2002. Understanding the Relationship Between Income Status and the Restrictions in Instrumental Activities of Daily Living Among Disabled Older Adults. Research Paper 83. Hamilton: Program for Research on Social and Economic Dimensions of an Aging Population.
RAINA. P.; WONG, M.; CHAMBERS, L. W.; DENTON, M. \& GAFNI, G., 2000. Describing Disability Among High and Low Income Status Among Older Adults in Canada. Research Paper 20. Hamilton: Program for Research on Social and Economic Dimensions of an Aging Population.

ROMANOW, R., 2002. Building on Values: The Future of Health Care in Canada. Commission on the Future of Health Care in Canada. Final Report. 28 November $2002<$ http://www.hc-sc. gc.ca/english/ care/romanow/>.

STANDING SENATE COMMITTEE ON SOCIAL AFFAIRS, SCIENCE AND TECHNOLOGY, 2002. The Health of Canadians - The Federal Role. Final Report. Volume Six: Recommendations for Reform. October $2002<$ http://www.parl.gc.ca/37/2/parlbus/commbus/senate/com-e/soci-e/rep-e/repoct02vol6-e.htm>.

STATISTICS CANADA, 1997. Low Income After Tax. 25 August 1999 <http://www.statcan.caenglish/IPS/ Data/13-592-XIB.htm>.

STATISTICS CANADA, 1999a. Health among older adults. Health Reports, 11:47-61.

STATISTICS CANADA, 1999b. Portrait of Seniors in Canada. $3^{\text {rd }}$ Ed. Ottawa: Statistics Canada.

TROTTIER, H. MARTEL, L.; HOULE, C.; BERTHELOT, J.-M. \& LÉGARÉ, J., 2000. Living at home or in an institution: What makes the difference for seniors? Health Reports, 11:49-59.

UNDP (United Nations Development Program), 1998. Human Development Report 1998. New York: Oxford University Press.

Submitted on January 21, 2003

Approved on February 20, 2003 